\title{
Conceptual Framework Development for Job Satisfaction in Fujian Banking Industry, China
}

\author{
Wang Yuxin \\ Postgraduate Centre, Limkokwing University Creative and Technology, Malaysia \\ E-mail: katherineamma@gmail.com \\ Muhammad Farooq \\ Postgraduate Centre, Limkokwing University Creative and Technology, Malaysia \\ E-mail: Farooq.buzdar2@gmail.com
}

Received: Dec. 23, 2018 Accepted: Jan. 14, 2019 Online published: Feb. 17, 2019

doi:10.5296/ijhrs.v9i1.14356 URL: https://doi.org/10.5296/ijhrs.v9i1.14356

\begin{abstract}
Job satisfaction is the major concern of employees and managers, which is an emotional reflection of employees at work and plays an important role in increasing job performance. If the job satisfaction of employees is lower than their expectation, they will reduce attendance with lower performance and even quit the job, which is the last thing that the managers expected. In addition, employees usually are unsatisfied when they involve a few parts of the job, or when they work overload with high work stress and feel uncomfortable to get along with their co-workers or supervisors at the workplace. Therefore, it is necessary to acknowledge the satisfaction of employees, when more than half of the Chinese workers were unsatisfied with their job. According to Herzberg's two factors theory, factors that influence employees' job satisfaction can be separated into two parts, hygiene factors, and satisfier factors, and they can be divided into many factors as well, such as job involvement, employment relationship and so on. While this study introduced three factors (job involvement, work stress, and employment relationship) that influence job satisfaction with previous studies and fundamental knowledge in Fujian Banking Industry, China. Furthermore, providing the research methodology of job satisfaction for future research.
\end{abstract}

Keywords: job involvement, work stress, employment relationship, job performance

\section{Introduction}

It is common that the banking industry is becoming more dynamic and complicate with 
higher competition in the world (Osman, 2014). Recently, with Chinese Yuan (RMB) depreciation to the lowest level, many investors do everything possible to transfer RMB to foreign currencies, to reduce the influence of their assets, which leads to the bad performance of many companies in the banking industry (Enoch, 2018). Therefore, it necessary to investigate whether the employees are satisfied with the job and find out a better way to increase their job satisfaction, to improve work efficiency, which will enhance the companies' performance (Bakotić, 2016). Through the survey of employee job satisfaction, managers can understand employees' opinions and improve communication in the organization, which is beneficial to enhance human resource development and management from a variety of perspectives.

With the increasing development of economic knowledge, employees are becoming the core competence of companies with their creations and innovation, especially talents. According to a Gallup survey of job satisfaction, more than half of the Chinese workers were unsatisfied with their job (Kenneth, 2018). Job satisfaction is the major concern of employees and managers. If the job satisfaction of employees is lower than their expectation, they will reduce attendance with lower performance and even quit the job, which is the last thing that the managers expected. Therefore, from the perspective of the organization, the level of employees' satisfaction not only influences organizational performance but also affects the outflow of talents, as well as the development of individual career. As employee job, satisfaction has an impact on productivity, absenteeism, turnover, and organizational citizenship behavior, HR managers must pay attention to the psychological indicator of employees and do their best to improve employee satisfaction. Thereby retaining and motivating the core employees of the organization (Dugguh \& Dennis, 2014).

To attract and retain those talents, managers should pay more attention to the necessities and feelings of them. Moreover, they can improve the professional life of the employees, while job satisfaction is an important psychological indicator of the quality of professional life of employees. Therefore, it is vital for organizations to analyze the factors that influence employees' job satisfaction, to adjust their management strategies to raise the job satisfaction of employees. Job involvement, work stress, and employment relationship can be adjusted by managers in the companies. When employees work with high stress like overload working, will decrease their job satisfaction. In addition, with high job involvement at work, employees will think they are important to the organizations so that they will be more satisfied with the job. Most of the employees are satisfied when having a good relationship with their co-workers, supervisors, and organizations.

In this study, it analyzed job involvement, work stress, and the employment relationship, as the main factors, to find the relationships between them and job satisfaction. If they have significant relationships on job satisfaction, it means managers can enhance employees' satisfaction by adjusting the involvement of workers, work stress and employment relationships at work.

\section{Literature Review}

The investigation is based on the previous studies about job satisfaction, and job involvement, 
work stress, and work condition have been considered as independent variables, which impact on job satisfaction (Pugliesi, 1999; Zopiatis, Constanti \& Theocharous, 2014; Raziq and Maulabakhsh, 2015). By analyzing the factors that influence job satisfaction, it will make employees' behavior become predictable (Zopiatis, Constanti \& Theocharous, 2014). In this part, every variable involved in the research would be illustrated in detail, with the definitions and relationships.

\subsection{Theoretical Framework}

\subsubsection{Job Satisfaction}

According to Vroom (1962), job satisfaction is an emotional reflection of employees at work, which plays an important role in increasing job performance. Locke (1976) described that employees would be delighted and pleasure through being praised or gain some achievement and work experiences. Moreover, poor satisfaction can be reflected in many aspects, Clark et al. (2012) discovered that employees who response unsatisfied with work, their absence rate and quit rate are higher than the others. Furthermore, job satisfaction can be applied to deeply acknowledge workers' general well-being, both in psychology and physics, not only through wage (Bender, Donohue \& Heywood, 2005).

Employees' satisfaction could be impacted by many aspects, for example, when they involve a few parts of the job when they work overload with high work stress and feel uncomfortable to get along with their co-workers or supervisors at the workplace (DeCarufel \& Schaan, 1990; Klassen \& Chiu, 2010; Raziq \& Maulabakhsh, 2015). Herzberg (2017) believed that factors that influence job satisfaction could be divided into several aspects, such as physical environment, social and personal psychological factors. Physical environment factors include work conditions, environment, and facilities; social factors refer to the attitude of employees at work, involvement, as well as the recognition and workload; personal psychological factors include views and attitudes of the job and the leadership style of the boss. In this study, job involvement, work stress, and employment relationship can be adjusted by both managers and employees' themselves.

\subsubsection{Job Involvement}

Kahn (1990) firstly defined job involvement, which means employees control themselves to integrate them and work roles. According to Kahn (1990), it can be divided into three dimensions: physical, cognitive and emotional. Job involvement is the psychological identification at work (Kanungo, 1982). In addition, it reveals the level of employees' self-definition, when they are a part of the work (Zopiatis, Constanti \& Theocharous, 2014). Blau (1985) reported that the degree of job involvement is conceptually related to how close the employees to the core work.

Maslach, Schaufeli \& Leiter, (2001) regard job involvement, which is energy, involvement, and inefficacy and job burnout, which is exhaustion, cynicism, and inefficacy, as the two poles of a three-dimensional continuum, which means job involvement is direct opposite to job burnout. In addition, they discovered that individuals with high involvement, will feel energetic at work, and can work harmoniously with others, and feel that they can fully meet 
the various requirements of the work. In contrast, the individuals with high burnout will feel exhausted, with a state of alienation from work and others.

\subsubsection{Work Stress}

Employees will feel work stress when they estimate work external requirements, which surpass their capability or resources (Lazarus, 2006). According to Karasek's (1979) demand-control model, psychological stress will occur through the combined influence of job requirements. The International Labor Organization stated a series of stress source from work in the banking industry, such as pressure on time, role conflicted, exceed job requirements, communication difficulty with customers, and a rising number of cases of stress and violence (Giga \& Hoel, 2003).

Work stress has become a vital problem in human resource management because it will lead to serious results for a company (Kelloway \& Day, 2005). If the employees work under high pressure, negative behavior and emotions will appear, both in psychology and physics (Gilboa et al., 2008). For instance, they will feel anxiety and depression, which will increase their desire for drinking and smoking (Valente et al., 2015). In addition, unsatisfied with work, absenteeism and worse performance are a normal phenomenon of excessive work pressure (Stansfeld \& Candy, 2006).

\subsubsection{Employment Relationship}

Employee relationship includes three aspects, such as the relationship between individuals and co-workers, the supervisors and the companies, which can be formed by companies' guidance (Biggs, Swailes \& Baker, 2016).

It is important to establish a harmonious relationship in corporate culture construction with a good corporate image. Moreover, a harmonious employment relationship is one of the important means to motivate employees and reduce work stress, which is also an important means to strengthen employee team awareness and equal cooperation spirit. Most Scholars have emphasized the significance of employment relationships in labor relations (Helper, Levine \& Bendoly, 2002). Chandrasekar (2011) interpreted that it is necessary to develop a good work environment for employees, and then employees will take advantage of it to work more effectively, and companies will benefit from it.

The employee relationship has two typical characteristics: a cooperative and harmonious relationship between the employer and the employee, and the relationship is actively constructed by the HR management of the company. It requires managers to continue to cultivate and care through hard work. This kind of employee relationship is a positive employee relationship (FordeCloud, 2018). Positive employee relationships are the most effective means for companies to attract and retain talent. According to two-factor theory of Herzberg (2017), attracting and retaining people with competitive salary is not a long-term method, while it is an internal requirement of employees by creating and maintaining a positive employee relations environment. In such an excellent work environment, the talents are delighted and satisfied with the works. 


\subsection{Conceptual Development}

\subsubsection{The Relationship Between Job Involvement and Job Satisfaction}

The degree of Employees' involvement at work will positively and directly effect on their job satisfaction (Robbins \& Judge, 2007). DeCarufel \& Schaan (1990) described that if the workers are interested in their jobs, they cannot live without the job, like eating and breathing and will highly involve in every part of it. Moreover, Chen \& Chiu (2009) described that those people who involved highly at work are more confident, they will not only finish their own work but also work for improving their performance.

In addition, many scholars have discovered a significant and positive relationship between job involvement and job satisfaction (Cheloha \& Farr, 1980; Brown, 1996). Kuruüzüm, Ipekçi \& Irmak (2009) constructed and examined an organizational commitment model, assuming relationships among job involvement, job satisfaction, and organizational commitment. According to their model, there is a relationship between job involvement and organizational commitments which influence job satisfaction as well. Therefore, they confirmed the significant relationship between job involvement and job satisfaction. Some recent studied have a similar conclusion as well that job involvement significantly and positively influence job satisfaction (Khan \& Nemati, 2011; Yeh, 2013; Zopiatis, Constanti \& Theocharous, 2014). Thus, the hypothesis can be stated as follow:

H1: There is a positive and significant relationship between job involvement and job satisfaction.

\subsubsection{The Relationship Between Work Stress and Job Satisfaction}

An empirical investigation has sought out four work-related stressors that can predict employees' unsatisfied feeling at work (Cooper, Rout \& Faragher, 1989). According to the research of Babin \& Boles (1996), the role stress as a type of work stress negatively influences on job satisfaction. Some studies have already discovered the significant relationship between work stress and job performance (Stamps \& Piedmonte, 1998; Applebaum et al., 2010). Many researches have shown that several negative results for employees are related to work pressure, such as decreased job satisfaction (Klassen \& Chiu, 2010). However, employees who work under lower stress will have higher satisfaction with their jobs (Grossi, Keil \& Vito, 1996; Lambert et al., 2004).

H2: There is a negative and significant relationship between work stress and job satisfaction.

\subsubsection{The Relationship Between Employment Relationship and Job Satisfaction}

Social information processing theory (SIP) figured out that attitudes of employees are developed when they interact with the others in a company (Salancik \& Pfeffer 1978). By the research of Kalleberg (1977), negative employment relationships with co-workers will decrease their job satisfaction, while it is same as when they have a bad relationship with their managers (Harrick, Vanek \& Michlitsch, 1986; Reiner \& Zhao, 1999). According to a discovery of Chandrasekar (2011), good relationships is the main factor that influences job satisfaction, instead of skills, money and so forth. The significant relationship was found by 


\section{Macrothink}

International Journal of Human Resource Studies

ISSN 2162-3058 2019, Vol. 9, No. 1

Clark, Oswald \& Warr, (1996), between employment relationship and job satisfaction, while employees who reported with great employment relationship has proved to be more satisfied with their job.

H3: There is a positive and significant relationship between employment relationship and job satisfaction.

\subsection{Conceptual Framework}

\subsubsection{Two-Factor Theory}
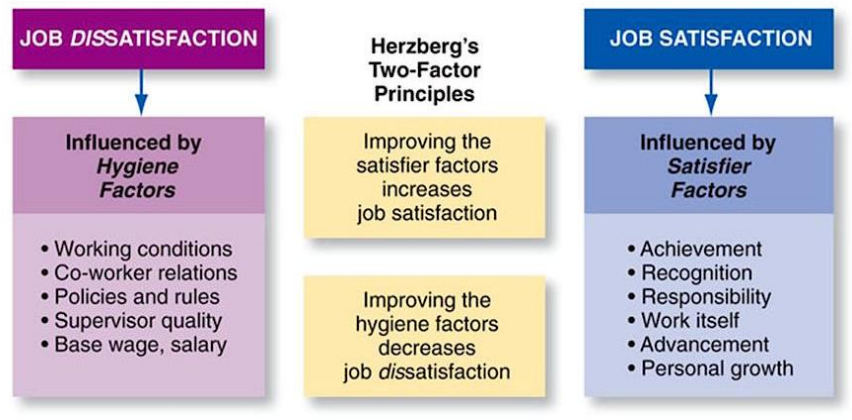

Figure 1. Herzberg's Two-factor Theory (Herzberg, 2017)

Herzberg (2017) proposed the two-factor theory, which divided relevant factors into two different aspects, satisfaction factors, and dissatisfaction factors. Satisfaction factors, including, achievement, recognition, work itself and so on, while they are satisfier factors that can make people satisfied and motivated. On the other hand, dissatisfaction factors, including working conditions, co-worker relations, policies and rules, salary and so on, are hygiene factors, which can be seen in figure 1 . He believes that these two factors are the main factors affecting employee performance. The hygiene factors are factors outside the work, they can eliminate job dissatisfaction and maintain the original work efficiency, but they cannot motivate people when they are improved. Satisfier factors are related to the work itself, they can generate a lot of incentives with satisfaction when they are improved.

\subsubsection{Work Stress Model}

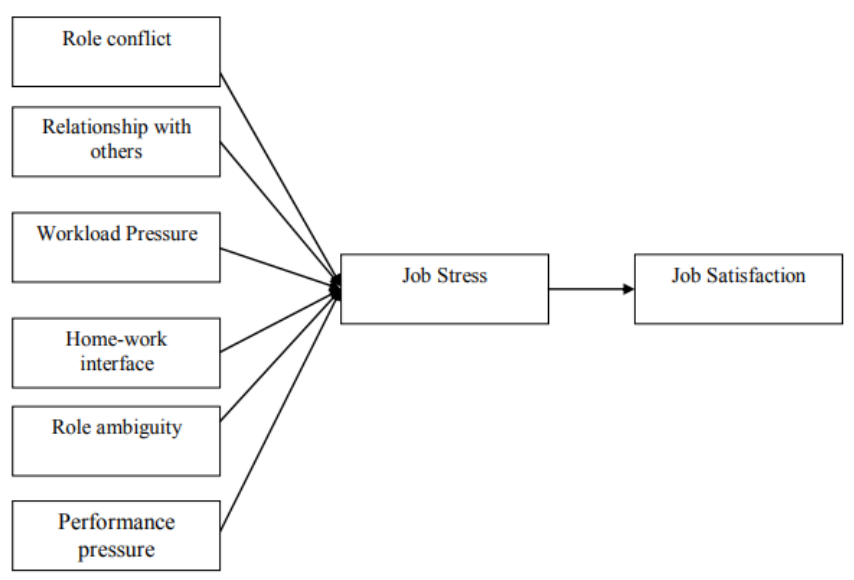

Figure 2. Job Stress and Satisfaction Model (Ahsan et al., 2009) 


\section{Macrothink}

International Journal of Human Resource Studies

ISSN 2162-3058 2019, Vol. 9, No. 1

In Job Stress and Satisfaction Model, which investigated by Ahsan et al. (2009), that Job stress can be divided into several small factors, which finally proved that job stress has a negative and significant influence on job satisfaction.

\subsubsection{Conceptual Framework}

Therefore, according to previous researches of job satisfaction, it shows the significant relationship between work involvement and job satisfaction, as well as the employment relationship and work stress. Therefore, the model can be adapted as follow:

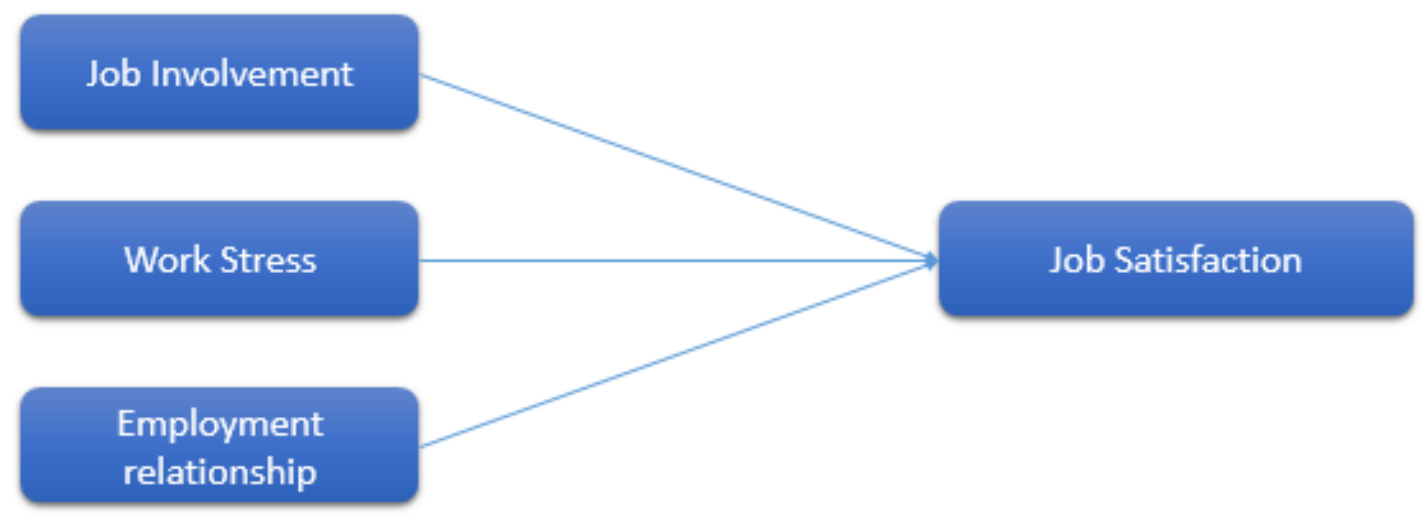

Figure 3. Conceptual Framework for Banking Industry

\section{Research Methodology}

Based on the different means of research, it can be divided into qualitative research methods and quantitative research methods (Trochim \& Donnelly, 2001). The research focuses on an investigation of the relationships between IVs (Job involvement, work stress, and employment relationship) and DV (job satisfaction) in Fujian banking industry of China. The research will apply quantitative research to analyze data, which collected by questionnaires, which is attached at the end of the report.

\subsection{Sampling}

\subsubsection{Target Population and Research Context}

The target population of the research is employees in Fujian banking industry of China. According to the statistics, until 2018, there were 3.689 million people live in Fujian Province in China (En.wikipedia.org, 2018). Furthermore, the research will be conducted by distributing through online questionnaires and hard-copy in Fujian, China, to analyze the employees' job satisfaction.

\subsubsection{Sampling}

According to the number of Fujian citizens, the sample size should be at least 384 respondents involved in the research. 


\subsection{Data Collection}

\subsubsection{Data Collection for the Study}

The paper primarily applied questionnaires for data collection. According to the previous studies and researches, the questionnaires were modified with the characteristics of Fijian bank employees, the survey was designed based on the previous questionnaires with Likert scale, by Tencent Questionnaire. The Tencent Questionnaire will be sent by social media and hard-copies. Employees can fill out the questionnaire according to their own situation, while Tencent Questionnaire is convenient so that the feedback can be seen online.

\subsubsection{Questionnaire Design}

The modified questionnaire was separated into two sections: basic information and job satisfaction and its factors results

Section one is about basic information, including gender, education, age, working years in the banking industry and ask whether they are working for a foreign company.

Section two is the questions about job satisfaction and their factors, which adapted from previous questionnaires by utilizing the Likert scale (Hse.gov.uk, 2018; Kanungo, 1982; Spector, 1985). Furthermore, it has been divided into 3 parts with different variables (job involvement, work stress, and employment relationship), and there are 5 questions for each of them.

Part I: Questions about job involvement including the involved level of work, activities, and decision-making, the interest level of the job and how much it closes to their goals.

Part II: Questions of work stress is evaluated by the degree of the tasks can be finished by the respondents, they can take a break at any time, and the flexibility level of the work schedule and workload, and they can finish tasks in time.

Part III: Questions about employment relationship, which is estimated by five questions, including the level of equal treated of female and male in the office, the supervisor respects all the officer, the respondents would like to work with their co-workers, everyone treated fairly with respect and the supervisor help them when they have problems with the client.

Part IV: Questions of job satisfaction, such as the degree of respondents' satisfaction with the job, working with their colleagues, their organization's activities, promotion, and workload.

\section{Conclusions}

Job satisfaction is important to both employees and managers, it can enhance employees' performance and efficiency, to improve companies' performance. While in China, only a few employees and managers pay attention to it. The study is aiming at analyzing different factors (job involvement, work stress, and employment relationship) that influence job satisfaction, to provide theories, conceptions and research methods for the future research about job satisfaction in Fujian, China. Through modifying the model, the research objectives can be confirmed. According to the literature review, the three IVs of the model are closely and 
directly associated with job satisfaction and can be observed at work. Therefore, the study is beneficial for both future researchers and practitioners. In future research, it can be examined by collecting data and data analysis. If the result shows the significant relationship between them and job satisfaction, the model will benefit the Chinese banking employees. Besides the employees, its address the niche in the human resources. Furthermore, researchers and practitioners can use the framework to investigate the performance of the organization and improve the employees' satisfaction.

\section{Acknowledgement}

Thanks for Dr. Zahir Bin Osman, Open University Malaysia. With his encouragement and guidance, we finish the journal successfully.

\section{References}

Ahsan, N. et al. (2009). A study of job stress on job satisfaction among university staff in Malaysia: Empirical study. European journal of social sciences, 8(1), 121-131.

Applebaum, D. et al., (2010). The impact of environmental factors on nursing stress, job satisfaction, and turnover intention. The Journal of nursing administration, 40, 323. https://doi.org/10.1097/NNA.0b013e3181e9393b

Babin, B. J., \& Boles, J. S. (1996). The effects of perceived co-worker involvement and supervisor support on service provider role stress, performance and job satisfaction. Journal of retailing, 72(1), 57-75. https://doi.org/10.1016/S0022-4359(96)90005-6

Bakotić, D. (2016). Relationship between job satisfaction and organisational performance. $\begin{array}{llll}\text { Economic research-Ekonomska istraživanja, } & 29(1),\end{array}$ https://doi.org/10.1080/1331677X.2016.1163946

Bender, K. A., Donohue, S. M., \& Heywood, J. S. (2005). Job satisfaction and gender segregation. Oxford economic papers, 57(3), 479-496. https://doi.org/10.1093/oep/gpi015

Biggs, D. M., Swailes, S., \& Baker, S. (2016). The measurement of worker relations: the development of a three-component scale. Leadership \& Organization Development Journal, 37(1), 2-12. https://doi.org/10.1108/LODJ-08-2012-0098

Blau, G. J. (1985). A multiple study investigation of the dimensionality of job involvement. Journal of vocational Behavior, 27(1), 19-36. https://doi.org/10.1016/0001-8791(85)90050-8

Brown, S. (1996). A meta-analysis of job involvement and its correlates. Psychological Bulletin, 34, 345-356.

Chandrasekar, K. (2011). Workplace environment and its impact on organisational performance in public sector organisations. International journal of enterprise computing and business systems, 1(1), 1-19.

Cheloha, R. S., \& Farr, J. L. (1980). Absenteeism, job involvement, and job satisfaction in an organizational setting. Journal of applied Psychology, 65(4), 467-473. https://doi.org/10.1037/0021-9010.65.4.467 
Chen, C. C., \& Chiu, S. F. (2009). The mediating role of job involvement in the relationship between job characteristics and organizational citizenship behavior. The Journal of social psychology, 149(4), 474-494. https://doi.org/10.3200/SOCP.149.4.474-494

Clark, A., Georgellis, Y., \& Sanfey, P. (2012). Job satisfaction, wage changes, and quits: Evidence from Germany. In 35th Anniversary Retrospective. Emerald Group Publishing Limited. 499-525. https://doi.org/10.1108/S0147-9121(2012)0000035041

Clark, A., Oswald, A., \& Warr, P. (1996). Is job satisfaction U-shaped in age?. Journal of occupational and organizational psychology, 69(1), 57-81. https://doi.org/10.1111/j.2044-8325.1996.tb00600.x

Cooper, C. L., Rout, U., \& Faragher, B. (1989). Mental health, job satisfaction, and job stress among general practitioners. Bmj, 298(6670), 366-370. https://doi.org/10.1136/bmj.298.6670.366

DeCarufel, A., \& Schaan, J. L. (1990). The impact of compressed work weeks on police job involvement. Canadian Police College Journal.

Dugguh, S. I., \& Dennis, A. (2014). Job satisfaction theories: Traceability to employee performance in organizations. IOSR journal of business and management, 16(5), 11-18. https://doi.org/10.9790/487X-16511118

En.wikipedia.org. (2018). Fujian. [online] Available: https://en.wikipedia.org/wiki/Fujian (Jan 10, 2019).

Enoch, Y. (2018). Yuan falls to lowest level of 2018 in longest losing streak in two years. [online] South China Morning Post. Available: https://www.scmp.com/business/banking-finance/article/2152280/chinas-yuan-hits-lowest-lev el-2018-suffering-longest-losing (Jan 10, 2019).

FordeCloud (2018). What Are Positive Employee Relations \& Why Are They Important? | Forde HR Cloud. [online] Fordehrcloud.com. Available: https://fordehrcloud.com/what-are-positive-employee-relations (Jan 10, 2019).

Giga, I. S., \& Hoel, H. (2003). Violence and stress at work in financial services.

Gilboa, S. et al. (2008). A meta-analysis of work demand stressors and job performance: examining main and moderating effects. Personnel Psychology, 61(2), 227-271. https://doi.org/10.1111/j.1744-6570.2008.00113.x

Grossi, E. L., Keil, T. J., \& Vito, G. F. (1996). Surviving "the joint": Mitigating factors of correctional officer stress. Journal of Crime and Justice, 19(2), 103-120. https://doi.org/10.1080/0735648X.1996.9721549

Harrick, E. J., Vanek, G. R., \& Michlitsch, J. F. (1986). Alternate work schedules, productivity, leave usage, and employee attitudes: A field study. Public Personnel Management, 15(2), 159-169. https://doi.org/10.1177/009102608601500206

Helper, S., Levine, D. I., \& Bendoly, E. (2002). Employee involvement and pay at US and 
Canadian auto suppliers. Journal of Economics \& Management Strategy, 11(2), 329-377. https://doi.org/10.1111/j.1430-9134.2002.00329.x

Herzberg, F. (2017). Motivation to work. Routledge. (Part II) https://doi.org/10.4324/9781315124827

Hse.gov.uk. (2018). Surveys for work related stress in the workplace. [online] Available: http://www.hse.gov.uk/stress/standards/step2/surveys.htm (Jan 10, 2019).

Kahn, W. A. (1990). Psychological conditions of personal engagement and disengagement at work. Academy of management journal, 33(4), 692-724.

Kalleberg, A. L. (1977). Work values and job rewards: A theory of job satisfaction. American sociological review, 124-143. https://doi.org/10.2307/2117735

Kanungo, R. N. (1982). Measurement of job and work involvement. Journal of applied psychology, 67(3), 341. https://doi.org/10.1037/0021-9010.67.3.341

Karasek, Jr, R. A. (1979). Job demands, job decision latitude, and mental strain: Implications for job redesign. Administrative science quarterly, 285-308. https://doi.org/10.2307/2392498

Kelloway, E. K., \& Day, A. L. (2005). Building healthy workplaces: what we know so far. Canadian Journal of Behavioural Science/Revue canadienne des sciences du comportement, 37(4), 223. https://doi.org/10.1037/h0087259

Kenneth, R. (2018). China Workers Unsatisfied On The Job, Poll Suggests. [online] Forbes.com.

Available: https://www.forbes.com/sites/kenrapoza/2012/07/09/china-workers-unsatisfied-on-the-job-po 1l-suggests/\#40e823632d7d (Jan 10, 2019).

Khan, K., \& Nemati, A. R. (2011). Impact of job involvement on employee satisfaction: A study based on medical doctors working at Riphah International University Teaching Hospitals in Pakistan. African Journal of Business Management, 5(6), 2241-2246.

Klassen, R. M., \& Chiu, M. M. (2010). Effects on teachers' self-efficacy and job satisfaction: Teacher gender, years of experience, and job stress. Journal of educational Psychology, 102(3), 741. https://doi.org/10.1037/a0019237

Kuruüzüm, A., Ipekçi, Ç. E., \& Irmak, S. (2009). Path analysis of organizational commitment, job involvement and job satisfaction in Turkish hospitality industry. Tourism review, 64(1), 4-16. https://doi.org/10.1108/16605370910948821

Lambert, E. G. et al., (2004). The effects of occupational stressors on jail staff job satisfaction. Journal of Crime and Justice, 27(1), 1-32. https://doi.org/10.1080/0735648X.2004.9721627

Lazarus, R. S. (2006). Stress and emotion: A new synthesis. Springer Publishing Company. (Part II)

Locke, E. A. (1976). The nature and causes of job satisfaction. Handbook of industrial and organizational psychology, 1297-1349. 
Maslach, C., Schaufeli, W. B., \& Leiter, M. P. (2001). Job burnout. Annual review of psychology, 52(1), 397-422. https://doi.org/10.1146/annurev.psych.52.1.397

Osman, Z. (2014). Conceptual framework development for customer loyalty in Malaysian commercial banking industry. International Journal of Management, IT and Engineering, 4(2), 197.

Pugliesi, K. (1999). The consequences of emotional labor: Effects on work stress, job satisfaction, and well-being. Motivation and emotion, 23(2), 125-154. https://doi.org/10.1023/A:1021329112679

Raziq, A., \& Maulabakhsh, R. (2015). Impact of working environment on job satisfaction. $\begin{array}{llll}\text { Procedia Economics } \quad \text { and } & \text { 717-725. }\end{array}$ https://doi.org/10.1016/S2212-5671(15)00524-9

Reiner, M. D., \& Zhao, J. (1999). The determinants of job satisfaction among United States air force security police: A test of rival theoretical predictive models. Review of public personnel administration, 19(3), 5-18. https://doi.org/10.1177/0734371X9901900301

Robbins, S., \& Judge, T. A. (2007). Organizational behavior (12th ed.). Upper Saddle River, New Jersey: Prentice-Hall.

Salancik, G. R., \& Pfeffer, J. (1978). A social information processing approach to job attitudes and task design. Administrative science quarterly, 224-253. https://doi.org/10.2307/2392563

Spector, P. E. (1985). Measurement of human service staff satisfaction: Development of the Job Satisfaction Survey. American journal of community psychology, 13(6), 693-713. https://doi.org/10.1007/BF00929796

Stamps, P. L. (1998). Nurses and work satisfaction: an index for measurement. AJN The American Journal of Nursing, 98(3), 16KK-16LL. https://doi.org/10.1097/00000446-199803000-00017

Stansfeld, S., \& Candy, B. (2006). Psychosocial work environment and mental health-a meta-analytic review. Scandinavian journal of work, environment \& health, 443-462. https://doi.org/10.5271/sjweh.1050

Trochim, W. M., \& Donnelly, J. P. (2001). Research methods knowledge base.

Valente, M. D. S. D. S. et al., (2015). Depressive symptoms and psychosocial aspects of work in bank employees. Occupational medicine, 66(1), 54-61. https://doi.org/10.1093/occmed/kqv124

VROOM, V. (1962). EGO-INVOLVEMENT, JOB SATISFACTION, AND JOB PERFORMANCE. Personnel Psychology, 15(2), pp.159-177. https://doi.org/10.1111/j.1744-6570.1962.tb01858.x

Yeh, C. M. (2013). Tourism involvement, work engagement and job satisfaction among frontline hotel employees. Annals of Tourism Research, 42, 214-239. https://doi.org/10.1016/j.annals.2013.02.002 


\section{Macrothink}

International Journal of Human Resource Studies

ISSN 2162-3058 2019, Vol. 9, No. 1

Zopiatis, A., Constanti, P., \& Theocharous, A. L. (2014). Job involvement, commitment, satisfaction and turnover: Evidence from hotel employees in Cyprus. Tourism Management, 41, 129-140. https://doi.org/10.1016/j.tourman.2013.09.013

\section{Copyright Disclaimer}

Copyright for this article is retained by the author(s), with first publication rights granted to the journal.

This is an open-access article distributed under the terms and conditions of the Creative Commons Attribution license (http://creativecommons.org/licenses/by/4.0/). 